удк 378.013.42-057.87: 378.663

Павло Смоляк

Національний університет біоресурсів

і природокористування України ORCID ID 0000-0003-0016-5561

DOI 10.24139/2312-5993/2020.08/306-317

\title{
СУТНІСТЬ І СТРУКТУРА ПОНЯТТЯ «СОЦІАЛЬНІ НАВИЧКИ СТУДЕНТІВ АГРАРНИХ ЗАКЛАДІВ ВИЩОЇ ОСВІТИ»
}

у статті соціальні навички трактуються як інтегративне психологічне утворення, необхідне для ефективної дії майбутнього фрахівця агропромислової галузі, і забезпечують йому досягнення успіху в обраній предметній області діяльності. Ці навички часто називають м'якими, надпрофесійними. Указується, що навичка - це інтегративне психологічне утворення, що дозволяє суб'єкту виконувати ті чи інші дії в автоматичному режимі без надмірного контролю з боку свідомості. Представлено результати відбору сочіальних навичок за допомогою методу експертної оцінки та на цій основі здійснено систематизацію соціальних навичок за групами, а саме: комунікативні, лідерські, керування емоціями, навички особистісного розвитку, валео-екологічні навички. 3 урахуванням різних сфер особистості розкривається структура соціальних навичок із виділенням емотивної, когнітивної та конативної складових. Виокремлюються специфічні показники сочіальних навичок, характерні для майбутніх фахівців агропромислової галузі.

Ключові слова: виховання, сочіальні навички, студенти аграрних закладів вищої освіти, когнітивна, емотивна, конативна складові соціальних навичок.

Постановка проблеми. В умовах швидкоплинних змін, зумовлених, з одного боку, розвитком постіндустріальної, технотронної цивілізації, інформаційного суспільства, розгортанням четвертої промислової революції (на думку футурологів, у зв'язку з розвитком робототехніки та штучного інтелекту зникне частина професій), а з іншого, - всезростаючим техногенним і антропогенним навантаженням на довкілля, глобальним потеплінням, змінами клімату, i, як наслідок, виникненням і стрімким поширенням небезпечних для життя і здоров'я людей смертоносних вірусів, інфекцій (ВІЛСНIД, поліомієліт, туберкульоз, пташиний, свинячий грип, SARS-CoV-2 та інші), виснаженням джерел традиційних енергетичних ресурсів, перед людством гостро постає питання перебудови, реорганізації освітніх практик, змісту, форм методів роботи. Це особливо важливо в умовах сучасного інтенсивного використання дистанційних, віддалених способів освіти, що реалізуються за допомогою різних програмних додатків, для проведення он-лайн конференцій, навчальних платформ, симуляторів, гаджетів і девайсів, що створюють доповнену, віртуальну реальність і слугують цілям підготовки 
фахівця, формування його ціннісного світогляду, соціально-схвалюваних зразків поведінки. У контексті таких викликів важливо забезпечити підготовку фахівців, які не тільки зможуть виконувати вузькопрофесійні задачі, а й налагоджувати конструктивну взаємодію, працювати в команді, лідирувати, постійно розвиватися, правильно планувати час, раціонально розпоряджатися ресурсами, орієнтуючись на принципи сталого розвитку суспільства, мінімізуючи згубний вплив на оточуюче нас середовище живої природи. Особливу актуальність цього питання відзначимо стосовно майбутніх фахівців біономічних професій типу «людина-природа», якими $є$ студенти аграрних закладів вищої освіти. Вирішення означеної проблеми корениться у площині ціннісного світогляду людини, який виявляється назовні соціально корисною поведінкою, що залежить від сформованості, вихованості відповідних навичок. Таким навичками $є$ соціальні, надпрофесійні навички успіху.

Аналіз актуальних досліджень. Різні аспекти виховання особистості, формування ії соціальних навичок знаходимо у працях педагогів-класиків: Я. А. Коменського, Й. Песталоцці, А. Дістервега (Коваленко, 2008), М. Пирогова, А. Макаренка, В. Сухомлинського (Сопівник, 2015) та інших. Значна увага формуванню різних соціально важливих психологічних утворень особистості приділяється у працях таких учених, як: І.Бех (Бех, 2006), Г. Шевченко (Шевченко, 2013), Г. Філіпчук, О. Коберник, І. Василькіський (Васильківський, 2018), Г. Васянович (Васянович, 2006), І. Сопівник (Сопівник, 2014), В. Франкл (Франкл, 2016), Е. Фромм та інші. Є низка праць, присвячених вивченню навичок відповідальної поведінки: Л. Колберг (Колберг, 2005), Ж. Піаже, Ж.-П. Сартр, Х. Хекхаузен та ін. Окремі вчені вивчали різні аспекти соціальних навичок, пов'язуючи їх із соціальним талантом (Н. Д. Левітов), соціальним інтелектом (Т. Хант, Е. Торндайк), лідерськими здібностями (Л. І. Уманський), соціальною обдарованістю (О.О.Бодальов), емоційним інтелектом (Д. Гоулман (Гоулман, 2018), М. Кетс де Врис (Кетс де Врис, 2007)), керування енергією (Дж. Лоер, Т. Шварц, 2018), навички щасливого житя «ікігаї» (Е. Гарсія, Ф. Міралес, 2018), резонансне лідерство (Е. Макі, Р. Бояцис, 2007), навички лідерства (Д. Алфімов (Алфімов, 2010), О. Василькова, Б. Головешко, І. Резнік (Резнік, 2007) Ю. Кращенко, А. Семенов, Р. Сопівник (Сопівник, 2015), Г. Тітов, В. Ягоднікова (Ягоднікова, 2006) та інші.

Мета статті - розкрити сутність і структуру поняття «соціальні навички студентів аграрних закладів освіти»

Методи дослідження. Нами було використано аналіз, синтез систематизацію, порівняння, узагальнення, абстрагування, метод експертної 
оцінки, що зробили можливим визначення поняття «соціальні навички студентів аграрних закладів вищої освіти».

Виклад основного матеріалу. Найвищою мірою прояву сформованості особистості, ії ціннісного світогляду $€$ дії, вчинки, поведінка суб'єкта, що відповідає соціальним стандартам і запитам, моральним критеріям, культурним вимогам і очікуванням оточуючих, соціальному статусу і тій ролі, яку індивід виконує в суспільстві. Тут маються на увазі усталені форми поведінки, якими є навички. Під поняттям «навичка» в педагогічній науці розуміють дії, складові частини яких стають автоматичними. При цьому зазначається, що діяльність людини, яка володіє необхідними навичками, реалізується швидше і продуктивніше. За видами навички розрізняють: рухові, мислительні, мовні, інтелектуальні, сенсорні, перцептивні, соціальні інші. Підкреслюється, що навичка засновується на знаннях про відповідні способи дій та виникає у результаті багаторазових повторень, вправлянь (Гончаренко, 1997, с. 221). У Педагогічному енциклопедичному словнику за редакцією Б. М. Бім-Бада (Бім-Бад, 2003) дещо розширюються межі розуміння поняття «навичка» і вказується, що це дія сформована шляхом повторення, яка характеризується високим рівнем засвоєння й відсутністю поелементної регуляції і контрою. Часто навичку трактують як уміння, доведене до автоматизму, а уміння - як здатність застосовувати набуті знання на практиці.

Таким чином, у нашому дослідженні під навичкою ми будемо розуміти таке складне, інтегративне психологічне утворення особистості, засноване на знаннях про певні способи дій, що дозволяє виконувати ті чи інші дії й операції з належною точністю і швидкістю, без надмірного контролю з боку свідомості, коли поведінкові акти реалізується автоматично. Навичка виникає в результаті багаторазового повторення дій і значно підвищує продуктивність. Людина, з метою адаптації до змінних умов середовища, упродовж життя змушена опановувати безліч навичок: навички спілкування, письма, налагодження стосунків, особистісного розвитку, навички самообслуговування, приготування їжі, гігієни, здорового способу життя, навички господарської діяльності, самоорганізації, управління часом, ресурсами, іншими людьми інші. Із цього широкого переліку нас цікавлять саме соціальні навички. Австралійські вчені Р. Пітерсі, Д.Трелоар, диференціюють побутові й соціальні навички, наголошуючи на тому, що перші дозволяють вирішувати завдання повсякденного житт, другі забезпечують контакт із оточуючими нас людьми (Пітерсі, 2006). Тобто, під соціальними навичками ми будемо розуміти такі навички, які дозволяють 
людині будувати стосунки з іншими людьми, налагоджувати комунікацію, конструктивну взаємодію, кооперувати зусилля, співпрацювати, домовлятися, працювати в команді, діяти з позиції керівника, лідера, або підлеглого чи послідовника, постійно розвиватись і дбати про власне здоров'я, яке необхідне для плідної взаємодії із собі подібними.

Сьогодні соціальні навички ототожнюють із «м'якими», надпрофесійними навичками успіху, які дозволяють людині працювати ефективно незалежно від предметної області. M’які навички, або «soft skills» відрізняються від «твердих навичок» (hard skills), які ще називають професійними навичками. Останні опановуються в результаті освоєння певної професії, отримання фаху. Для володіння «твердими» навичками треба засвоїти знання, сформувати вміння, компетентності в певній предметній області (інженерія, медицина, економіка, сільське господарство тощо). М'які, або соціальні навички є універсальними, вони необхідні кожному фахівцю, незалежно від змісту професійної підготовки

У науковій літературі ми знаходимо безліч тих навичок, які можна назвати соціальними, або м'якими, надпрофесійними навичками. Так, О. Лободинська, О. Гриджук серед таких навичок виділяють ті, що мають найбільший попит серед українських роботодавців, зокрема спроможність швидко навчатися, аналітичне, критичне та стратегічне мислення, ініціативність, здатність до роботи в команді, уміння комплексно вирішувати проблеми, емоційний інтелект, уміння управляти проєктами, сформовані навички письмового й усного спілкування (Лободинська, 2020, с. 116-121). Дослідниця О. Гура у статті «Особливості розвитку м'яких навичок студентів IT-спеціальностей засобами навчальних Scrum-проектів» виділяє ті соціальні навички, які, з точки зору авторки, необхідні майбутнім програмістам для ефективної дії у виробничих ситуаціях. Серед таких навичок виокремлюються: навички роботи в команді (здатність працювати в команді і виконувати свої завдання, поєднуючи індивідуальні навички 3 іншими членами команди для досягнення загальної мети); навички пошуку інформації (уміння знаходити, опрацьовувати та синтезувати інформацію, що надходить із різних джерел); креативні навички (здатність знаходити нові рішення); навички прийняття рішень (визначити найкращий шлях, що забезпечує максимальну ефективність і успішність отримання результату 3 мінімальними витратами особистих чи командних ресурсів); навички управління конфліктами (мінімізувати соціальну напругу); навички критичного мислення (здатність ставити під сумнів інформацію, що надходить зовні, а також припускати можливість власної помилки); навички презентації 
(здатність у найбільш вигідній формі презентувати свої ідеї оточенню); навички лідерства (здатність приймати бізнес-рішення і керувати підлеглими); комунікативні навички (здатність передавати інформацію людям чітко, просто, ефективно і зрозуміло); навички гнучкості (спроможність за потреби змінюватися, застосовувати нові рішення); навички «тайм-менеджменту» (оволодіння методиками і технологіями планування особистого часу з метою підвищення ефективності та раціональності його використання).

К. Коваль у статті «Розвиток «soft skills» у студентів - один із важливих чинників працевлаштування» пропонує свою класифікацію соціальних навичок, які автор асоціює з якостями особистості (Коваль, 2015, с. 162-167) і виділяє індивідуальні якості (здатність приймати рішення, формулювати завдання, позитивне мислення й оптимізм, орієнтація на клієнта); комунікативні якості (здатності зрозуміло формулювати думки, дружнього спілкування, взаємодії з різними типами людей, урахування альтернативних точок зору, спілкування, створення презентацій, урахування культурних і міжнаціональних особливостей); управлінські якості (здатності працювати в команді, мотивувати, об'єднувати, навчати інших, передбачати ризики, планувати та керувати часом).

Важливо враховувати вимоги, які диктуються державними інституціями, що визначають стандарти якості освіти. Так, Національне агентство із забезпечення якості вищої освіти акцентує на необхідності формування у фахівців різних типів професій соціальних, надпрофесійних навичок, а у своєму глосарії визначає сутність цього понятт. Зокрема зазначається, що «soft skills» («м'які навички», «соціальні навички» чи «навички успішності») дозволяють випускникам закладів вищої освіти бути успішними на своєму робочому місці. До soft skills зараховують навички комунікації, лідерство, здатність брати на себе відповідальність, працювати в критичних умовах, уміння полагоджувати конфлікти, працювати в команді, управляти своїм часом, розуміння важливості deadline (вчасного виконання поставлених завдань), здатність логічно і критично мислити, самостійно приймати рішення, креативність. Іноді, до соціальних навичок також зараховують знання іноземних мов, у першу чергу - англійської мови. Вимагається. щоб кожен заклад вищої освіти мав власну політику стосовно розвитку soft skills у своїх здобувачів вищої освіти та викладачів. Ця політика має детермінуватися співпрацею з працедавцями та випускниками. Іноді під «soft skills» розуміють «transferable skills (навички, що їх можна переносити). Тут мається на увазі, що ці навички є цінними на будь-якому робочому місці, незалежно від професійної сфери (Глосарій НАЗяВО, 2019). 
Нами проаналізовано інформацію на сайтах окремих агрокомпаній України і з'ясовано, що сучасні роботодавці все охочіше віддають перевагу претендентам із яскраво вираженими soft skills. Провідні компанії (і не тільки) до претендентів на вакансії висувають вимоги, у яких значаться психологічні утворення, що $є$ результатом формування м'яких, соціальних навичок. Наприклад, корпорація АМАКО підкреслює важливість ініціативності, відповідальності, орієнтації на клієнта; Компанія «Миронівський хлібопродукт» - трудолюбивість, відповідальність; Агрохолдинг «Мрія» - дисциплінованість, відповідальність, уміння приймати швидкі рішення; «Вітагро» - чесність, мотив високих досягнень, комунікабельність; БТУ-центр України - порядність відповідальність, лідерство, відкритість до всього нового, екологічна культура, екологобезпечна поведінка та інше. На сайтах HR-менеджменту для східної Європи навіть виділяється топ 10 soft skills, які особливо цікавлять працедавців, а саме: комунікативні навички, комп'ютерна і технічна грамотність, міжособистісні навички, дослідницькі навички, навички адаптивності, навички управління проєктами, вирішення проблем, навички експертизи і вдосконалення бізнес-процесів, навички трудової етики, навички емоційного інтелекту (ТОП-10, 2020).

Значний інтерес у руслі досліджуваної проблеми викликає кластер навичок, які обнародувані на офіційних веб-ресурсах Всесвітнього економічного форуму в Давосі і будуть затребувані до 2025 року. Серед пропонованих навичок виділені: аналітичне мислення та інноваційність; активне навчання та стратегії навчання; розв'язання складних проблем; критичне мислення та аналіз; креативність, оригінальність та ініціативність; лідерство та соціальний вплив; використання технологій, моніторинг та контроль; створення технологій та програмування; витривалість, стресостійкість та гнучкість; логічна аргументація, розв'язання проблем та формування ідей (Нова українська школа, 2020). 3-поміж них, більшість можна віднести до соціальних навичок. У той самий час, світовими лідерами і фахівцями відзначено, що до 2025 року 50 \% усіх працівників потребуватимуть перекваліфікації через зростання впровадження технологій; близько 40 \% працівників потребуватимуть перекваліфікації тривалістю півроку чи менше; критичне мислення та розв'язання проблем посідають перше місце серед навичок, за якими, на думку роботодавців, зростатиме популярність протягом наступних п'яти років; уперше з'являються такі навички, як активне навчання (active learning), витривалість (resilience), стресостійкість (stress tolerance) та гнучкість (flexibility) (Нова українська школа, 2020). 
Ми проаналізували різні джерела, склали перелік соціальних навичок (40 найменувань) і запропонували потенційним працедавцям, іншим експертам (керівники агрокомпаній, керівники аграрних закладів вищої освіти, студентський актив відповідних 3ВО, науково-педагогічні працівники) здійснити експертний відбір і оцінку тих соціальних навичок, які з їх точки зору $\epsilon$ важливими для досягнення успіху, професійної самореалізації, адаптації випускників аграрних закладів вищої освіти в АПК, агробізнесі, сфері сільського господарства. За результатами проведеної дослідної роботи отримані соціальні навички було згруповано і сконструйовано їх кластер, а саме: комунікативні навички (спілкування, публічні виступи, переконання, ведення переговорів, дипломатичні навички, навички тактовної поведінки); лідерські (неформального впливу на послідовників, роботи в команді, управління часом, наставницькі навички); керування емоціями (емпатії, навички стресостійкості, самовладання); навички особистісного розвитку (самореалізації, самоактуалізації, самовдосконалення, підвищення каліфікації, самоменеджмент); валео-екологічні навички (організації харчування, навички догляду за тілом, раціонального режиму праці і відпочинку, етичного поводження із живими організмами та природою). Остання група соціальних навичок підкреслює специфічність категорії фахівців біономічних професій типу «людина-природа», які матимуть контакт із землею, живими організмами, тваринами і рослинами та, з огляду на виклики XXI ст., зобов'язані піклуватися про зменшення техногенного й антропогенного навантаження на довкілля, дотримуватись біоетики Альберта Швейцера.

Важливо, виходячи зі змісту пропонованих визначень, окреслити сутність самого поняття «соціальні навички студентів аграрних закладів вищої освіти», під яким ми будемо розуміти таке інтегративне психологічне утворення, що засновується на гуманітарних знаннях про комунікацію, лідерство, керування емоціями, особистісний розвиток, біоетику та професійні знання в галузі агропромислового комплексу, сільського господарства і дозволяє в автоматичному режимі будувати плідні стосунки зі соціальним оточенням, досягати успіху на робочому місці, постійно оновлювати знання та ділитися ними здійснювати професійну діяльність із використанням інноваційних екологобезпечних технологій.

Для визначення складових соціальних навичок скористаємося компонентною моделлю особистості, розробленою академіком І. Бехом (Бех, 2017). Адаптуємо згадану модель, видозмінюючи іï відповідно до особливостей досліджуваного нами психологічного утворення. Оскільки соціальні навички студентів аграрних закладів вищої освіти базуються на 
знаннях, то в основі таких навичок має бути когнітивний компонент, що включає знання про комунікацію, лідерство, керування емоціями, особистісний розвиток, біоетику та професійні знання в галузі агропромислового комплексу, сільського господарства. Проте, знати мало, треба мати поштовх до дії та відповідне ставлення до предмету самореалізації, тобто емотивний компонент, що включає потребу у відповідній соціальній дії, самореалізації, високих досягненнях, емоцію, позитивне, ціннісне ставлення до побудови плідних стосунків, спілкування, налагодження співпраці, лідерства, саморозвитку, самоактуалізації, збереження власного здоров'я та природного середовища. I третій, важливий компонент - конативний передбачає готовність до виконавських дій із реалізації потенціалу навички, перетворювальну активність у руслі плідної взаємодії 3 соціальним оточенням, діяльність із позиції лідера, роботу в команді, саморозвиток, здоров'язбереження та екологобезпечну поведінку.

Висновки та перспективи подальших наукових розвідок. Таким чином, під поняттям «соціальні навички студентів аграрних закладів вищої освіти» ми розуміємо таке інтегративне, психологічне утворення, що засновується на гуманітарних знаннях про комунікацію, лідерство, керування емоціями, особистісний розвиток, біоетику та професійних знаннях у галузі агропромислового комплексу, сільського господарства, що дозволяє, без значних затрат нервової і психічної енергії, в автоматичному режимі, будувати плідні стосунки із соціальним оточенням, досягати успіху на робочому місці, постійно оновлювати знання та ділитися ними, здійснювати професійну діяльність із використанням інноваційних екологобезпечних технологій.

У структурі соціальних навичок студентів аграрних закладів вищої освіти нами виділено: когнітивний компонент - знання про соціальні навички; емотивний компонент - включає потребу в застосуванні соціальних навичок, потребу у високих досягненнях та емоційнопозитивне, ціннісне ставлення до плідної соціальної взаємодії; конативний компонент - передбачає готовність до виконавських дій із реалізації потенціалу соціальних навичок та відповідну перетворювальну активність у соціальному і природному середовищі.

Метод експертної оцінки дозволив виокремити найбільш важливі соціальні навички та систематизувати їх за групами, а саме: комунікативні; лідерські; керування емоціями; навички особистісного розвитку; валеоекологічні навички. 


\section{ЛITEPATУРА}

Алфімов, Д. В. (2010). Зміст феномену «лідерські якості особистості». Педагогіка формування творчої особистості у вищій і загальноосвітній школах, 11, 44-51 (Alfimov, D. V. (2010). The content of the phenomenon "leadership qualities of the individual". Pedagogy of creative personality formation in higher and general education institutions, 11, 44-51).

Бех, І. Д. (2006). Виховання особистості. Київ: Либідь (Bekh, I. D. (2006). Education of personality. Kyiv: Lybid).

Бех, І. Д. (2017). Компонентна модель сходження зростаючої особистості до духовних цінностей. Теоретико-методичні проблеми виховання дітей та учнівської молоді, Вип. 21 (1), 6-20 (Bekh, I. D. (2017). A component model of the ascent of a growing personality to spiritual values. Theoretical and methodological problems of raising children and students, Issue 21 (1), 6-20). Retrieved from: http://nbuv.gov.ua/UJRN/Tmpvd_2017_21\%281\%29_3. 3.

Бояцис, Р. Макки, Э. (2007). Резонансное лидерство: самосовершенствование и построение плодотворных взаимоотношений с людьми на основе активного сознания, оптимизма и эмпатии. М.: Альпина Бизнес Букс (Boiatsis, R., Mackie, E. (2007). Resonant leadership: self-improvement and building fruitful relationships with people based on active consciousness, optimism and empathy. M.: Alpina Business Books).

Васильківський, І. П., Сопівник, Р. В. (2018). Зміст і структура і методики виховання емоційного інтелекту учнів середнього шкільного віку. Духовність особистості: методологія, теорія і практика, 3, 48-61 (Vasylkivskyi, I. P., Sopivnik, R. V. (2018). The content and structure and methods of educating the emotional intelligence of middle school students. Spirituality of personality: methodology, theory and practice, 3, 48-61).

Васянович, Г. П. (2006). Творимо особистість. Львів: Норма (Vasianovych, Н. Р. (2006). We create a personality. Lviv: Norma).

Гарсія, Е., Міралес, Ф. (2018). Ікігаї. Японські секрети довгого і щасливого життя. Харків: Віват (Garcia, E., M irales, F. (2018). Ikigai. Japanese secrets of a long and happy life. Kharkiv: Vivat).

Глосарій. Національне агентство забезпечення якості вищої освіти (2019). (Glossary. National Agency for Quality Assurance in Higher Education (2019). Retrieved from: https://naqa.gov.ua/wpcontent/uploads/2020/01/\%D0\%93\%D0\%BB\%D0\%BE\%D1\%81\%D0\%B0\%D1\%80\%D1 $\% 96 \%$ D0\%B9.pdf.

Гончаренко, С. У. (1997). Український педагогічний словник. Київ: Либідь (Honcharenko, S. U. (1997). Ukrainian pedagogical dictionary. Kyiv: Lybid).

Кетс де Вріс, М. (2007). Мистика лідерства. Развитие эмочионального интелекта. М.: Альпина Бизнес Брукс (Cats de Vries, M. (2007). The mystique of leadership. Development of emotional intelligence. M .: Alpina Business Brooks).

Коваленко, Є. І., Белкіна, Н. І. (2006). Історія зарубіжної педагогіки. Київ: Центр навчальної літератури (Kovalenko, Ye. I., Belkina, N.I. (2006). History of foreign pedagogy. Kyiv: Center for Educational Literature).

Коваль, К. О. (2015). Розвиток «soft skills» у студентів - один з важливих чинників працевлаштування. Вісник Вінницького політехнічного інституту, № 2, 162-167 (Koval, K. O. (2015). The development of "soft skills" in students is one of the important factors of employment. Bulletin of Vinnytsia Polytechnic Institute, 2, 162-167).

Кольберг, Л. (1994). Развитие моральных суждений. В Г. А. Цукерман, Психология саморазвития: задача для подростков и их педагогов: пособие для учителей. 
М.: Фирма «Интерпракс» (Kohlberg, L. (1994). Development of moral judgments. In G. A. Zuckerman, Psychology of self-development: a task for adolescents and their teachers: a guide for teachers. Moscow).

Лободинська, О. М., Гриджук, О. Є. (2020). Формування соціальних навичок студентів: проблеми й перспективи. Освітянські проблеми вищої школи. Науковий вісник НЛтУ України, Вип. 3, № 3, 116-121 (Lobodynska, O. M., Hrydzhuk, O. Ye. (2020). Formation of students' social skills: problems and prospects. Educational problems of higher school. Scientific Bulletin of NLTU of Ukraine, Issue 3, № 3, 116-121). Retrieved from: https://nv.nltu.edu.ua/Archive/2020/30 3/22.pdf.

Лоер, Дж., Шварц, Т. (2018). Живи на повну. Керуй енергією, а не часом - стань успішним і щасливим. Харків: Віват (Loer, J., Schwartz, T. (2018). Live to the fullest. Manage your energy, not your time - become successful and happy. Kharkiv: Vivat).

Нова українська школа (2020). Якими будуть основні 10 навичок у 2025 рочі - Всесвітній економічний форум опублікував список (Давос) (New Ukrainian school (2020). What will be the top 10 skills in 2025 - The World Economic Forum has published a list (Davos). Retrieved from: https://nus.org.ua/news/yakymy-budut-osnovni-10-navychok-u-2025rotsi-vsesvitnij-ekonomichnyj-forum-opublikuvav-spysok/.

Педагогический энциклопедический словарь (2003). М.: Большая Российская энциклопедия (Pedagogical encyclopedic dictionary (2003). M.: Great Russian Encyclopedia).

Пітерсі, М. (2008). Маленькі сходинки. Програма раннього втручання для дітей із затримкою розвитку. Книга 7. Самообслуговування та соціальні навички. Рівне: ОМнI (Peters, M. (2008). Small steps. Early intervention program for children with developmental delays. Book 7. Self-service and social skills. Rivne).

Резнік, С. М. (2007) Формування управлінських умінь і навичок у майбутніх інженерів у вищих технічних навчальних закладах (автореф. дис. ... канд. пед. наук). Київ (Reznik, S. M. (2007). Formation of managerial skills and abilities of future engineers in higher technical education institutions (PhD thesis abstract). Kyiv).

Сопівник, І. В. (2014). Виховання моральної відповідальності сільської молоді. Київ (Sopivnyk, I. V. (2014). Education of moral responsibility of rural youth. Kyiv).

Сопівник, Р. В. (2015). Формування лідерських якостей майбутніх фахівців агропромислової галузі. Виховання особистості в контексті професійної підготовки студентів аграрних вищих навчальних закладів, (сс. 75-99). КиївНіжин: Видавець ПП Лисенко М.M. (Sopivnyk, R. V. (2015). Formation of leadership qualities of future specialists in the agro-industrial sector. Education of the personality in the context of professional training of students of agricultural higher education institutions, (pp. 75-99). Kyiv-Nizhyn: Publisher PE Lysenko M.M.).

Топ-10 Soft skills востребованных работодателями (2020) (Top 10 Soft skills required by employers (2020). Retrieved from: https://hr-elearning.ru/top-10-soft-skills-navykovvostrebovannykh-raboto datelyami/

Франкл, В. (2016). Людина в пошуках справжнього сенсу. Психолог у конитаборі. Харків: «Харківська книжкова фабрика» (Frankl, V. (2016). Man in search of true meaning. Psychologist in a concentration camp. Kharkiv: "Kharkiv Book Factory").

Шевченко, Г. П. (2013). Духовно-культурні чінності виховання Людини. Луганськ (Shevchenko, H. P. (2013). Spiritual and cultural values of human education. Luhansk).

Шинкарук, В. Д., Сопівник, Р. В., Сопівник, І. В. (2015). Теорія та історія соціального виховання в зарубіжних країнах. Київ: ЦП «Компринт» (Shynkaruk, V. D., Sopivnyk, R. V., Sopivnyk, I. V. (2015). Theory and history of social education in foreign countries. Kyiv).

Ягоднікова, В. В. (2006). Формування лідерських якостей старшокласників в особистісно орієнтованому виховному процесі загальноосвітньої школи 
(автореф. дис. ... канд. пед. наук). Луганськ (Yahodnikova, V. V. (2006). Formation of leadership qualities of high school students in the personality-oriented educational process of secondary school (PhD thesis abstract). Luhansk).

\section{PEЗЮME}

Смоляк Павло. Сущность и структура понятия «социальные навыки студентов аграрных высших учебных заведений».

В статье социальные навыки трактуются как интегративное психологическое образование, необходимые для эффективного действия будущего специалиста агропромышленной отрасли, и обеспечивают ему достижение успеха в любой предметной области деятельности. Эти навыки часто называют надпрофессиональными. Указывается, что навык - это интегративное психологическое образование, кторое позволяет субъекту выполнять те или иные действия в автоматическом режиме без чрезмерного контроля со стороны сознания. Представлены результаты отбора социальных навыков с помощью метода экспертной оценки и на этой основе осуществлена систематизация социальных навыков по группам, а именно: коммуникативные, лидерские навыки, навыки управление эмоциями, навыки личностного развития, валео-экологчческие навыки. С учетом различных сфрер личности раскрывается структура социальных навыков с выделением эмотивной, когнитивной и конативной составляющих. Представлены специфические показатели сочиальных навыков, характерные для будущих специалистов агропромышленной отрасли.

Ключевые слова: воспитание, сочиальные навыки, студенты аграрных высших учебных заведений, когнитивная, эмотивная, конативна составляющие социальных навыков.

\section{SUM M ARY}

Smoliak Pavlo. The essence and structure of the concept "social skills of students of agricultural higher education institutions".

The article treats social skills as an integrative psychological education necessary for the effective action of the future specialist in the agro-industrial sector and ensure his success in the chosen subject area. It is emphasized that such skills are often called soft skills, superprofessional. It is noted that "social skills of students of agricultural higher education institutions" is an integrative, psychological education, which is based on humanitarian knowledge of communication, leadership, emotion management, personal development, bioethics and professional knowledge in the field of agriculture, which allows without significant expenditure of nervous and mental energy, in automatic mode, to build fruitful relationships with the social environment, to succeed in the workplace, to constantly update and share knowledge, to carry out professional activities using innovative environmentally friendly technologies.

Using the method of expert evaluation, the results of selection of social skills of students of agricultural higher education institutions are presented and on this basis their systematization is carried out by groups, namely: communication skills (communication, public speaking, persuasion, negotiation, diplomatic skills, tactful behavior); leadership (informal influence on followers, teamwork, time management, mentoring skills); emotion management (empathy, stress management skills, self-control); personal development skills (self-realization, self-actualization, self-improvement, advanced training, self-management); valeo-ecological skills (nutrition organization, body care skills, rational mode of work and rest, ethical treatment of living organisms and nature).

Using the component model of the personality (I. Bekh), the article reveals the structure of social skills of students of agricultural higher education institutions and 
highlights the following components, namely: cognitive component - knowledge of social skills; emotional component - includes the need to apply social skills, the need for high achievements and emotionally positive, value-based attitude to fruitful social interaction; conative component - involves readiness for executive action to realize the potential of social skills and appropriate transformational activity in the social and natural environment.

Key words education, social skills, students of agricultural higher education institutions, cognitive, emotional, conative components of social skills.

\title{
Удк 378.147:796.071.4]:796.012.4:001.895
}

\author{
Микола Чхайло \\ Сумський державний педагогічний \\ університет імені А.С. Макаренка \\ ORCID ID 0000-0002-7368-5202 \\ Наталія Скачедуб \\ Сумський державний педагогічний \\ університет імені А.С. Макаренка \\ ORCID ID 0000-0002-2249-4203
}

DOI 10.24139/2312-5993/2020.08/317-329

\section{ІННОВАЦІЙНІ ТЕХНОЛОГІЇ НАВЧАННЯ РУХОВИХ ДІЙ У ПРОФЕСІЙНІЙ ПІДГОТОВЦІ МАЙБУТНІХ ФАХІВЦІВ ФІЗИЧНОЇ КУЛЬТУРИ}

У статті розглянуто проблему впровадження інновачійних технологій навчання рухових дій у професійній підготовці майбутніх фрахівців фрізичної культури. Із метою виявлення доцільності використання електронних дидактичних технологій у профресійній підготовці фрахівців із фізичної культури було проведено анкетування серед викладачів фізкультурно-спортивних кафедр закладів вищої педагогічної освіти. Визначено педагогічні умови впровадження інновачійних технологій навчання рухових дій у професійну підготовку майбутніх фрахівців із фізичної культури. Розроблено комп'ютерну програму системи навчання рухових дій і тестування вмінь аналізувати техніку виконання рухових дій виду спорту на підставі ії візуального спостереження (модуль-додаток «Відеозавдання» для системи дістанційного навчання Moodle). Розроблено структурно-функціональну модель навчання рухових дій, яка описує технологію інноваційної діяльності навчання рухових дій із виду спорту.

Ключові слова: інформаційні технології, заклади вищої педагогічної освіти, електронні засоби навчання, майбутні фрахівці фрізичної культури, профресійна підготовка, рухові дії.

Постановка проблеми. Інноваційний шлях розвитку національної системи освіти є стратегічним завданням державної політики. Основні засоби його вирішення концентруються у площині розробки методології, структури і змісту інновацій, реалізації комплексу заходів упровадження в освітню діяльність.

Стосовно системи фізкультурної освіти впровадження інноваційних технологій вимагає обґрунтованих науково-методологічних положень, 